\title{
Ukraine on the Way Toward Sustainable Development
}

\section{Zamkevych Bogdan}

Bila Tserkva National Agrarian University (BNAU), Soborna Square, 8/1, Bila Tserkva, Kyiv region, 09117, Ukraine; rectorat@ btsau.net.ua;

Author to whom correspondence should be addressed; E-Mail: avatar.ikar11@google.com Tel.: +38-05-0075-0147.

Received: 30 July 2014 / Accepted: 6 November 2014 / Published: 7 November 2014

\begin{abstract}
The article is devoted to the research of state consumer spending behavior as a source of the sustainable economic development in Ukraine. The research proves that there is a reversible relation between the HDI and the level of shadow economy. In the consumer spending structure the expenditure on the environment protection, intellectual and physical development are on the lowest level whereas the expenditure on public order processing, safety and judiciary are unreasonably high. In Ukraine during 2002-2017 there is an obvious trend of the HDI increase under a fall of shadow economy level, and in 2007-2012 vice versa - under a level increase of shadow economy the HDI decreases. Economic growth, corruption overcoming, optimization of the household consumer spending structure and economic management system in order to guarantee a comfortable life for Ukrainians is an urgent and essential strategy of the sustainable development of Ukraine. The main directions of increasing the human development index are identified with the aim of determination the strategies on the way toward European integration.
\end{abstract}

Keywords: sustainable development; Ukrainian economy; consumer spending; human development index; shadow economy.

\section{Introduction.}

The recent decisive factor of production was the land, later it was the capital considered as a set of tools, nowadays it is a man himself who is increasingly becoming a crucial factor, with his capacity for learning, which is revealed through scientific knowledge and his ability to solidarity, his ability to anticipate and meet the needs of other people [1]. In other words, the decisive value of society is man 
himself and his development. Thus, much attention is paid to the damage which is done to human resources, potential employment and human health by the pollution and environmental deterioration. Human development is considered to be a key social global issue that concerns all life aspects. The prospects for the development of each individual, society and civilization depend on the depth and consistency of its decision. The basis of the solution of the above mentioned problem is the concept of sustainable human development.

Human development index (HDI) is the indicator of the human development. This index reflects the level of national achievements in the most important socioeconomic sectors and shows the level of satisfaction by personal material and cultural needs in consumer amenities which are mainly characterized by quantity indexes which abstract from their quality meaning (purchasing capacity, income, volume of goods and services consumption, the level of education, health care, culture etc.).

The dynamics of the human development index ranks in some countries are offered in the table 1 . It is characteristic that the human development index ranks constantly increase within recent years in the USA, the European countries, Belarus and the Russian Federation, and the Ukrainian rank decreased by 12 points - from 66 in 2005 to 78 in 2012.

Table 1. Dynamics of the human development index ranks $[3,4,5]$.

\begin{tabular}{lllll}
\hline Country & \multicolumn{5}{c}{ HDI ranks } \\
\hline & 2005 & 2010 & 2011 & 2012 \\
\hline United States & 4 & 4 & 4 & 3 \\
\hline Japan & 12 & 11 & 10 & 10 \\
\hline Poland & 44 & 41 & 39 & 39 \\
\hline Belarus & 62 & 61 & 51 & 50 \\
\hline Russian Federation & 68 & 65 & 50 & 50 \\
\hline Ukraine & 66 & 69 & 78 & 78 \\
\hline
\end{tabular}

Obviously the problem of human life quality improvement is a key question in the Ukrainian state policy. The directions of its solution can be established by the comparison of dynamic human development index (HDI) analysis and balance of the household consumer spending to market economy. This will allow realizing the strategy of the Ukrainian economic development toward the European integration and it will accelerate the socialization of the Ukrainian community.

\section{Results and Discussion.}

Three important economic sectors integrate all the models of social policy - life quality, effectiveness of the economy management and equity which prevents a social pressure. In the research, human development index computation [6] is usually based on methodology published in the Libanova E. investigation [2], as well as on the methodology of United Nations Statistics Division [7]. The following factors were taken into account for the human development index computation: probability of life, purchasing capacity and personal income, environmental factor which is characterized by domestic and drinking water use, population health, creative intelligence which is characterized by research paper financing, education and safety of life. 
The main sources of human development are the components of the state consumer spending expenses for: social safety and social security, health care, education, intellectual and physical development, environment protection as well as salaries, in other words all together it is a factor of human development (FHD). It is logical that the increase of the factor of human development defines the increase of human development index which can be accepted as a criterion of the level of sustainable development. The dynamics of the Ukrainian economy state doesn't prove such sequence dependence. For example, in 2007-2010 with a increase of the FHD the index of human development decreases, since 2010 and further on the index of human development slightly changes because of a considerate decrease of the FHD (shown in Figure 1).

Figure 1. Dynamics of the index of human development and the FHD $[6,8,9,10]$.

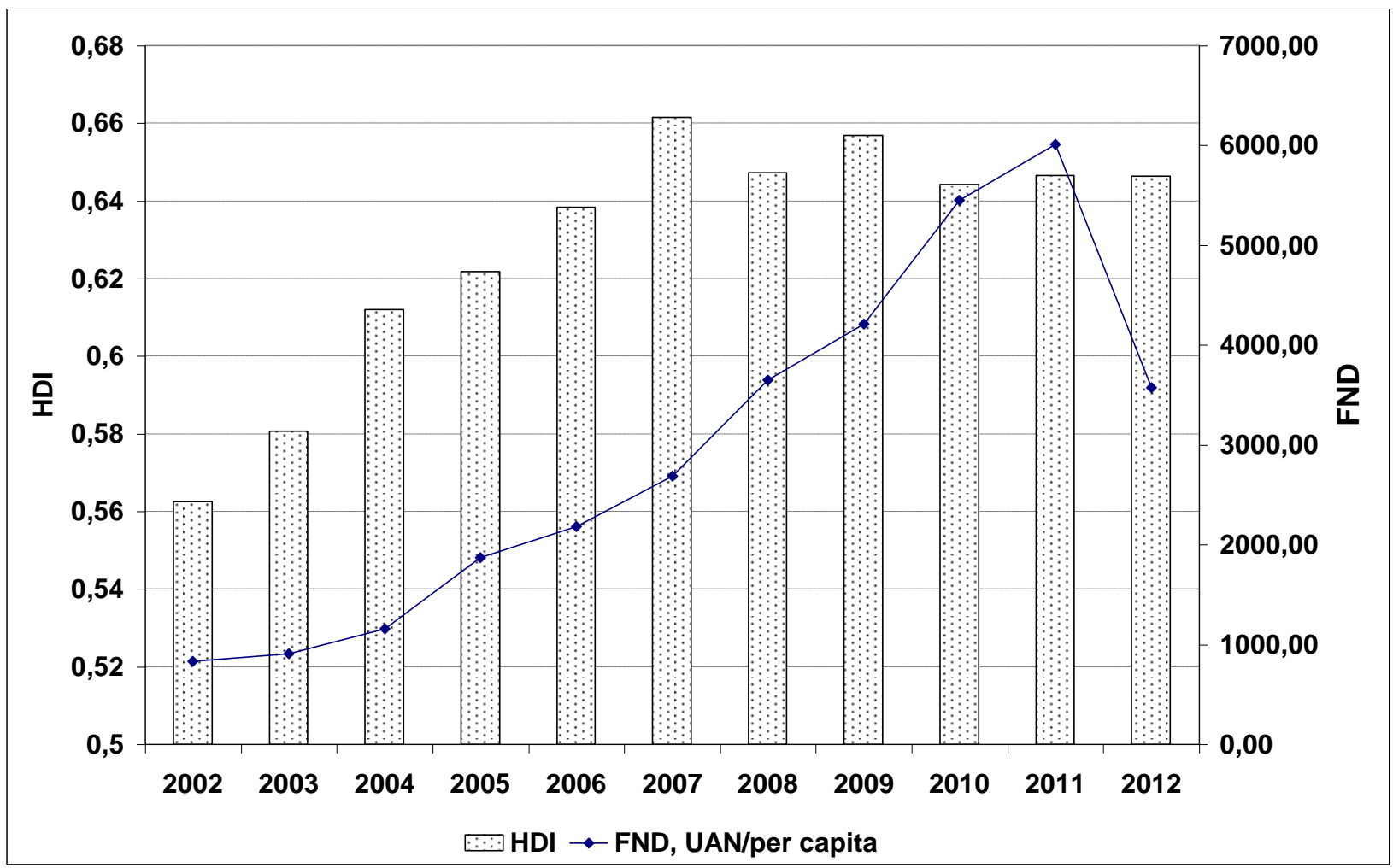


Figure 2. Dynamics of the FHD [8, 9, 10, 11].

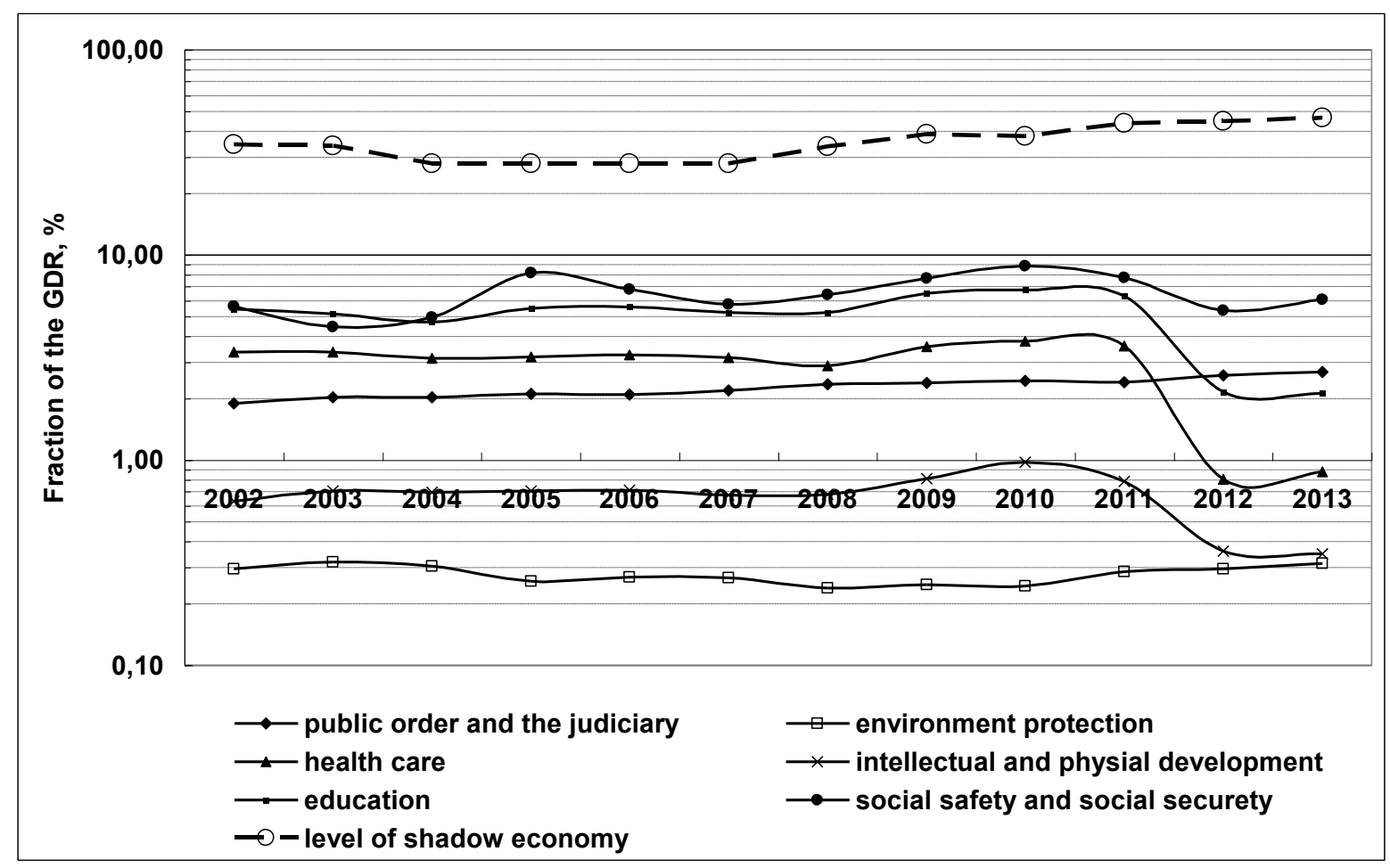

In order to determine the reasons of such a state, all the components of the FHD were analyzed (shown in Figure 2).

The FHD increase in 2007-2010 is accompanied by the level increase of the shadow economy which is explained by the HDI decrease caused by inappropriate state consumer spending in the personal interests. The level of shadow economy is a lot higher than the FHD level, that's why even significant changes of the FHD level after 2010 can't seriously affect the HDI level.

In the consumer spending structure the expenditure on the environment protection, intellectual and physical development are on the lowest level whereas the expenditure on public order processing, safety and judiciary are unreasonably high. It is possible to increase indirectly the HDI by the elimination of this contradiction even without changes of total costs.

The research proves that there is a reversible relation between the HDI and the level of shadow economy (shown in Figure 3). In Ukraine during 2002-2007 there is an obvious trend of the HDI increase under a fall of shadow economy level, and in 2007-2012 vice versa - under a level increase of shadow economy the HDI decreases. 
Figure 3. Dependence of the index of human development of the shadow economy level [3, $11]$.

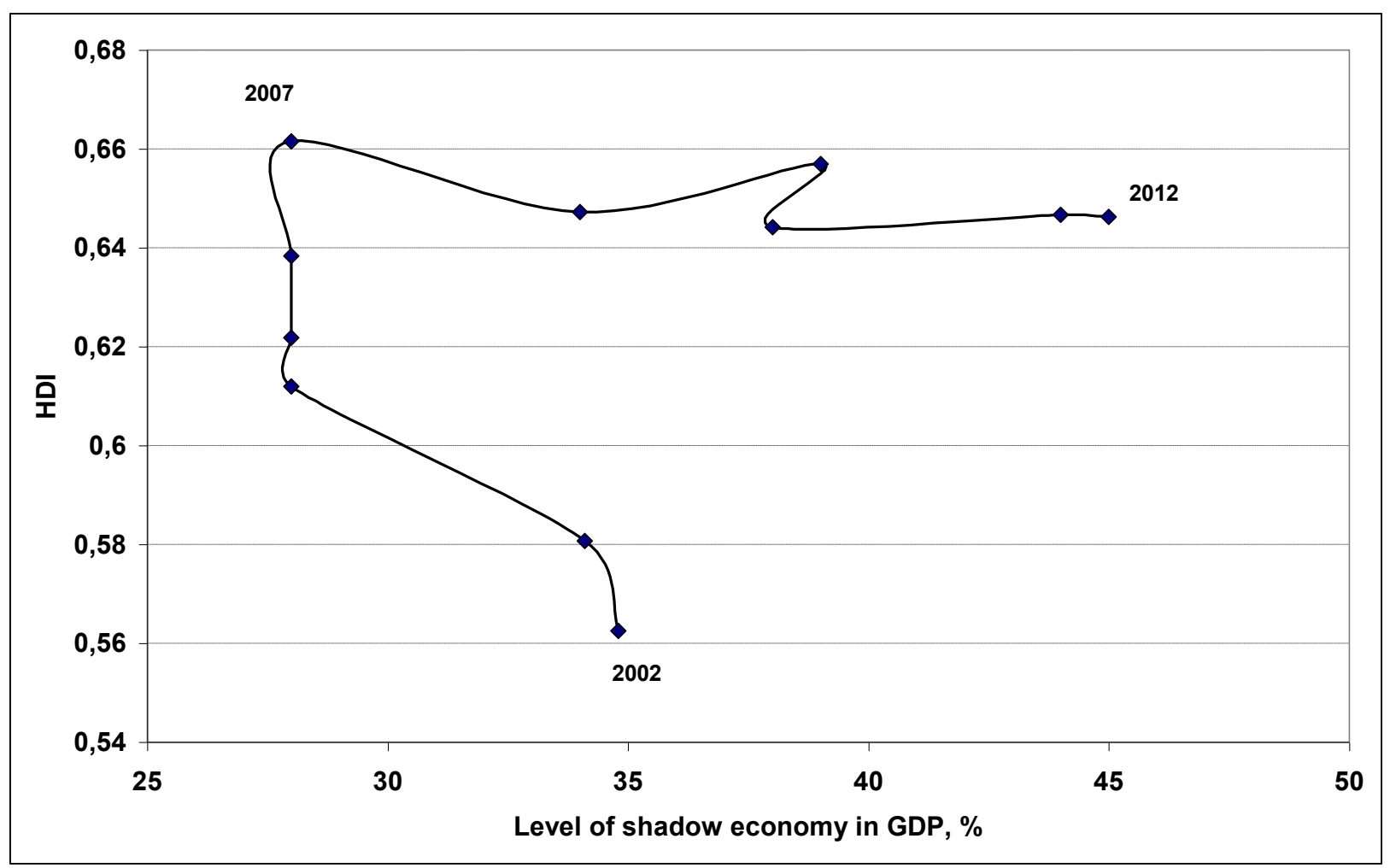

In 2012 in the countries with high HDI ranks (for example the USA, Poland) and in Ukraine the fraction of the household consumer spending in the GDP was almost the same (in Ukraine even slightly higher), and with such HDI ranks Ukraine considerably fell behind (shown in Table 2). This economic state can be explained by considerate quantitative differences between household consumer spending, in Poland household consumer spending is 2,8 times higher and it is next larger in the USA than in Ukraine. While the level of shadow economy in Ukraine is twice higher than in Poland and five times higher than in the USA.

Table 2. Comparison of the economic state in the USA, Poland and Ukraine

\begin{tabular}{lcccc}
\hline Country & HDI ranks & $\begin{array}{c}\text { Household } \\
\text { consumer } \\
\text { spending [12], } \\
\text { bln.US dollars }\end{array}$ & $\begin{array}{c}\text { Fraction of the } \\
\text { household } \\
\text { consumer } \\
\text { spending in the } \\
\text { GDP[12], } \%\end{array}$ & $\begin{array}{c}\text { Fraction of the } \\
\text { shadow } \\
\text { economy in the } \\
\text { GDP, } \%\end{array}$ \\
\hline The USA & 4 & 35118 & 68,6 & $8,6[13]$ \\
\hline Poland & 39 & 7773 & 60,6 & $25,0[14]$ \\
\hline Ukraine & 78 & 2746 & 71,0 & $45,0[15]$ \\
\hline
\end{tabular}

\section{Conclusions}

At the beginning of the 21s century general human values became priority in the strategic planning of the state development and the ideas of the sustainable development which stipulates the qualitative 
rather than quantitative growth and the balance in social, economic and ecological aspects determines their base. System-based approach in the study of the problem concerning the balanced economic development under the conditions of the transformations is the most adequate and comprehensible.

Economic growth, corruption overcoming, optimization of the household consumer spending structure and economic management system in order to guarantee a comfortable life for Ukrainians is an urgent and essential strategy of the sustainable development of Ukraine. Primarily it is about economic growth, corruption overcoming, ecological concern, health protection supporting, intellectual and physical development.

\section{Acknowledgments}

The author thanks the Editors and referees for their helpful comments and suggestions.

\section{References and Notes}

1. Ivan Pavlo. II [Electronic resource] - Access mode http://www.ji.lviv.ua/n19texts/encyklika.htm. Title from the screen.

2. National report about human development 2011 Ukraine: on the way toward social involving / Institute of population science and social research named after M.V. Ptukha NAS of Ukraine; Insitute of political and ethno-national research named after I.F. Kuras NAS of Ukraine and Ukrainian center of social reforms. [Electronic resource] http://www.undp.org.ua/files/ua_95644NHDR_2011_Ukr.pdf. - Title from the screen.

3. United Nations Development Programm. Human Development Index and its components. [Електронний ресурс] - Access mode https://data.undp.org/dataset/Table-1-Human-DevelopmentIndex-and-its-components/wxub-qc5k - Title from the screen.

4. Summary Human Development Report 2013 The Rise of the South: Human Progress in a Diverse World [Electronic resource] - r Access mode http://hdr.undp.org/sites/default/files/hdr2013_en_summary.pdf. - Title from the screen.

5. Summary Human Development Report 2010 20th Anniversary Edition The Real Wealth of Nations: Pathways to Human Development [Electronic resource] - Access mode http://www.indiawaterportal.org/sites/indiawaterportal.org/files/Human\%20Development\%20Report_ UNDP_2010.pdf. - Title from the screen.

6. Zamkevych B.M. Human development and life quality in Ukraine under the conditions of the economic transformations. Economy and Management of A.I.C.: Composite book of scientific papers / Bila Tserkva National Agrarian University.- Bila Tserva, 2011. - Ed. 6(89). - 204 p.

7. Villem de Vris. Substantial estimations: factors of progress, progress of factors / Villem de Vris. // Statistics of Ukraine. - 2002. - № 2 (17), - P. 76-84.

8. Modernization of Ukraine - our strategic choice: Annual Message of the President of Ukraine to the Verkhovna Rada of Ukraine. - K., 2011. - 416 P. [Electronic resource] - Access mode: www.president.gov.ua. - Title from the screen.

9. Factors of the budget implemention of Ukraine from January to December 2012-2013 [Electronic resource] - Access mode http://www.minfin.gov.ua/file/link/392182/file/DBU_ZBU.pdf. - Title from the screen. 
10. Inflation index (Ukraine) [Electronic resource] - Access mode http://index.minfin.com.ua/index/infl/. - Title from the screen.

11. National Institute of strategic research. Shadow economy in Ukraine: scale and directions of overcoming. [Electronic resource] $\quad-\quad$ Access mode http://www.niss.gov.ua/public/File/2011_table/1201_dop_new.pdf. - Title from the screen.

12. Househond consumer spending in Ukraine, 1990-2012 [Electronic resource] - Access mode http://nauka.kushnir.mk.ua/makroekonomika/household_consumption_expenditure/ household_consumption_expenditure_ukraine.html\#t1. - Title from the screen.

13. In Bolivia, the USA and Russia people the most avoid paying taxes. [Electronic resource] Access mode. http://tyzhden.ua/News/47715. - Title from the screen.

14. Shadow economy increase in the EU countries. All the Europe and Luxebbourg. Edition 6(88), 2014. [Electronic resource] - Access mode. http://www.alleuropa.ru/rost-tenevoy-ekonomiki-vstranach-es. - Title from the screen.

15. Shadow economy in Ukraine. [Electronic resource] - Access mode http://kobzar.at.ua/news/tinova_ekonomika_ukrajini/2013-02-09-1693. - Title from the screen.

(C) 2014 by the authors; licensee MDPI, Basel, Switzerland. This article is an open access article distributed under the terms and conditions of the Creative Commons Attribution license. 